\title{
Clinical Reasoning: A 65-year-old man with asymmetric weakness and paresthesias
}

Yohei Harada, MD, Hisham Elkhider, MD, Neil Masangkay, MD, and Mitesh Lotia, MD

Neurology ${ }^{\circledR}$ 2019;93:856-861. doi:10.1212/WNL.0000000000008444
Correspondence

Dr. Harada

yharada@uams.edu

\section{Section 1}

A 65-year-old man with well-controlled diabetes presented with 3 months of progressive leftside predominant weakness accompanied by painless paresthesias of his bilateral upper and lower extremities. The onset was with tingling and numbness in his toes, which later involved his fingers. Over a few weeks, he developed progressive weakness of his left lower extremity followed by the right lower extremity and later involvement of both upper extremities. By the time of presentation, the patient was unable to sit or walk without support and reported weight loss of 35 pounds over 3 months. The patient denied any toxic substance exposure, insect bites, recent illness or travel, family history of neuropathy, or any episodes suggestive of recurrent compressive neuropathies. His examination showed moderately severe asymmetric weakness (Medical Research Council scale: $3-4 / 5$ on the left, $4-5 / 5$ on the right) of the upper and lower extremities (distal more than proximal). There was asymmetric muscle atrophy; however, deep tendon reflexes were $2+$ in the right biceps and triceps, $1+$ in the left biceps, triceps, and bilateral ankles, and absent in the knees bilaterally. The sensory examination revealed left-sided predominant loss of pinprick in a patchy distribution in legs and loss of vibration sense in the toes. The remaining neurologic examination was unremarkable.

\section{Questions for consideration:}

1. What is the differential diagnosis?

2. What investigations should be considered?

\section{GO TO SECTION 2}




\section{Section 2}

The differential diagnosis for a subacute onset of progressive weakness and paresthesias of the extremities is broad. The CNS is less likely to be involved given the absence of upper motor neuron signs and intact cranial nerve examination. Some key clinical features to consider for peripheral nervous system involvement are asymmetric motor and sensory findings, patchy distribution of sensory changes, and predominantly distal weakness. One should consider mononeuritis multiplex, plexopathy, and polyradiculopathy high on the differential. ${ }^{1}$ The causes for mononeuritis multiplex include the following:

1. Inflammatory/autoimmune (e.g., vasculitis, atypical chronic inflammatory demyelinating polyneuropathy [CIDP])

2. Hereditary (e.g., hereditary neuropathy with liability to pressure palsy [HNPP])

3. Infectious (e.g., hepatitis, HIV, parvovirus, Lyme disease, leprosy)

4. Malignancy (e.g., paraneoplastic neuropathy, lymphoma)

5. Systemic (e.g., sarcoidosis, amyloidosis)

Vasculitis typically presents with sensory or sensory-motor involvement with an asymmetric/multifocal pattern, lower limb involvement, and distal predominance along with electrodiagnostic features of axonal polyneuropathy. HNPP is an episodic, multifocal hereditary neuropathy associated with PMP22 deletion. Classic clinical presentation is characterized by transient pressure palsies without pain but with focal motor and sensory symptoms in a single nerve distribution or the brachial plexus. The electrophysiologic features are slowed distal motor latencies, most frequently in the median and peroneal nerves, conduction slowing over entrapment sites, slowed sensory conduction velocities, and conduction block in acutely symptomatic nerves. Systemic diseases, malignancy, and infectious causes would need to be explored as well given the recent weight loss, although physical examination did not reveal findings suggestive of these conditions.

Blood tests revealed unremarkable complete blood count, comprehensive metabolic panel, mildly reduced vitamin $B_{12}$ $(163 \mathrm{pg} / \mathrm{mL})$, normal methylmalonic acid $(0.20 \mu \mathrm{mol} / \mathrm{L})$, hemoglobin Alc 6.1\%, creatine kinase $91 \mathrm{IU} / \mathrm{L}$, erythrocyte sedimentation rate $18 \mathrm{~mm} / \mathrm{h}$, negative antinuclear antibodies, $\mathrm{M}$ protein, and nonreactive HIV I and II antibodies. CSF analysis revealed an elevated cell count of $22 / \mu \mathrm{L}$ (lymphocytic $89 \%$ ) and elevated protein $127 \mathrm{mg} / \mathrm{dL}$. MRI of the brain and entire spine with and without contrast was unremarkable except for mild degenerative disc disease in cervical and lumbar spine without any nerve root enhancement, effectively ruling out localization to the CNS and nerve roots.

Nerve conduction studies revealed conduction block in the forearm of the bilateral ulnar and left median nerves and mildly slowed conduction velocity of the left median and ulnar motor nerves (figure and tables 1 and 2). The left superficial peroneal sensory response was absent. The left sural, radial, and right ulnar sensory responses showed mildly reduced amplitudes and conduction velocities (table 1). F-wave latencies were prolonged in the left ulnar nerve (table 1). Needle EMG showed widespread active denervation in upper and lower extremities on the left side and abnormal spontaneous activity (fibrillation potentials and positive sharp waves) from cervical and lumbar paraspinal muscles (table 1).

\section{Questions for consideration:}

1. What is the interpretation of the clinical findings and testing, including nerve conduction studies?

2. What additional testing would you perform?

Figure Nerve conduction study results

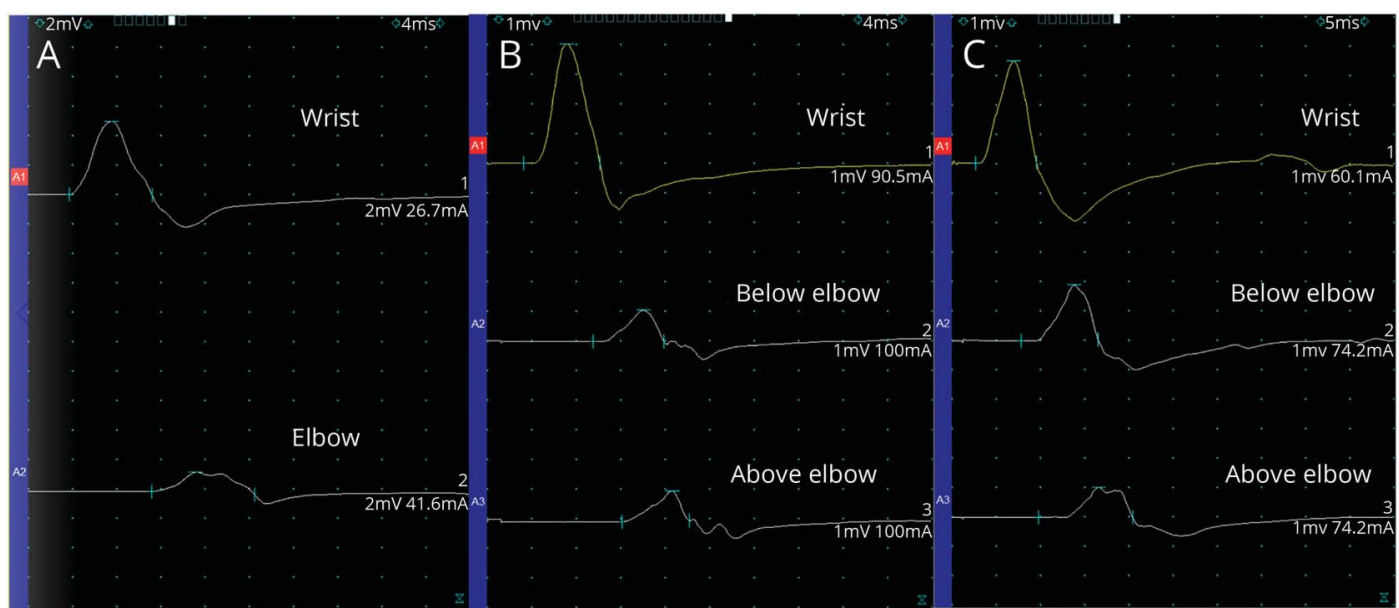

(A) Left median motor conduction studies with stimulation at wrist and elbow and recordings from abductor pollicis brevis. (B) Left ulnar motor conduction studies with stimulation at wrist and elbow and recordings from first dorsal interosseous. (C) Right ulnar motor conduction studies with stimulation at wrist and elbow and recordings from the abductor digiti minimi. 
Table 1 Nerve conduction study

\begin{tabular}{|c|c|c|c|c|c|c|}
\hline Nerve stimulated & Stimulation site & Recording site & Latency, ms & $\begin{array}{l}\text { Amplitude (motor mV, } \\
\text { sensory } \mu \mathrm{V} \text { ) }\end{array}$ & $\begin{array}{l}\text { Conduction } \\
\text { velocity, } \mathrm{m} / \mathrm{s}\end{array}$ & F wave, ms \\
\hline \multicolumn{7}{|l|}{ Motor NCS } \\
\hline \multirow[t]{2}{*}{ L median } & Wrist & APB & 3.7 & 5 & & 33.2 \\
\hline & Elbow & APB & 11.2 & 1.3 & 36 & \\
\hline \multirow[t]{2}{*}{ R median } & Wrist & APB & 3.3 & 10 & & 22.9 \\
\hline & Elbow & APB & 9.0 & 9.7 & 48 & \\
\hline \multirow[t]{3}{*}{ L ulnar } & Wrist & ADM & 2.6 & 2.6 & & 42.2 \\
\hline & Below elbow & ADM & 7.9 & 1.3 & 51 & \\
\hline & Above elbow & ADM & 9.8 & 1.3 & 51 & \\
\hline \multirow[t]{3}{*}{ L ulnar } & Wrist & FDI & 3.3 & 4.0 & & \\
\hline & Below elbow & FDI & 9.5 & 1.1 & 39 & \\
\hline & Above elbow & FDI & 12.1 & 1.1 & 38 & \\
\hline \multirow[t]{3}{*}{$\mathrm{R}$ ulnar } & Wrist & ADM & 2.6 & 3.5 & & 26.9 \\
\hline & Below elbow & ADM & 7.8 & 1.9 & 50 & \\
\hline & Above elbow & ADM & 9.7 & 1.0 & 51 & \\
\hline \multirow[t]{3}{*}{ L peroneal } & Ankle & EDB & 4.3 & 4.5 & & 53.2 \\
\hline & Fibular head & EDB & 10.1 & 3.6 & 57 & \\
\hline & Popliteal fossa & EDB & 12.2 & 3.7 & 53 & \\
\hline \multirow[t]{2}{*}{ L tibial } & Ankle & $\mathrm{AH}$ & 4.0 & 3.8 & & 54.5 \\
\hline & Popliteal fossa & $\mathrm{AH}$ & 12 & 3.0 & 53 & \\
\hline \multicolumn{7}{|l|}{ Sensory NCS } \\
\hline L median & Wrist & Digit II & 2.8 & 10.9 & 52 & \\
\hline R median & Wrist & Digit II & 3.2 & 13.4 & 47 & \\
\hline L ulnar & Wrist & Digit V & 2.7 & 16.3 & 45 & \\
\hline R ulnar & Wrist & Digit V & 2.9 & 6.3 & 45 & \\
\hline L radial & Forearm & $\begin{array}{l}\text { Anatominal } \\
\text { snuff box }\end{array}$ & 2.0 & 7.4 & 54 & \\
\hline $\mathbf{R}$ radial & Forearm & $\begin{array}{l}\text { Anatominal } \\
\text { snuff box }\end{array}$ & 1.7 & 10.6 & 64 & \\
\hline L sural & Ankle & Lower leg & 3.7 & 3.8 & 38 & \\
\hline $\begin{array}{l}\text { L superficial } \\
\text { peroneal }\end{array}$ & Ankle & Dorsum of foot & $N R$ & $N R$ & $N R$ & \\
\hline
\end{tabular}

Abbreviations: $\mathrm{ADM}=$ abductor digiti minimi; $\mathrm{AH}=$ abductor hallucis; $\mathrm{APB}=$ abductor pollicis brevis; $\mathrm{EDB}=$ extensor digitorum brevis; $\mathrm{FDI}=$ first dorsal interosseous; $\mathrm{NR}=$ no response. 
Table 2 EMG summary

\begin{tabular}{|c|c|c|c|c|c|c|c|c|c|c|}
\hline \multirow[b]{2}{*}{ Muscle } & \multirow{2}{*}{$\begin{array}{l}\text { Insertional } \\
\text { IA }\end{array}$} & \multicolumn{3}{|c|}{ Spontaneous activity } & \multicolumn{3}{|c|}{ Motor unit morphology } & \multicolumn{3}{|l|}{ Recruitment } \\
\hline & & $\begin{array}{l}\text { Fibrillation/ } \\
\text { positive } \\
\text { waves }\end{array}$ & Fasciculation & Other & Duration & Amplitude & Polyphasic & $\begin{array}{l}\text { Number of } \\
\text { motor unit } \\
\text { action } \\
\text { potentials }\end{array}$ & $\begin{array}{l}\text { Firing } \\
\text { rate }\end{array}$ & Activation \\
\hline L deltoid & Normal & None & None & None & Normal & Normal & Normal & Normal & Normal & Full \\
\hline $\begin{array}{l}\text { L triceps } \\
\text { brachii }\end{array}$ & Normal & $+/-$ & None & None & Normal & Normal & Normal & $\begin{array}{l}\text { Mildly } \\
\text { reduced }\end{array}$ & Normal & Full \\
\hline $\begin{array}{l}\text { L flexor carpi } \\
\text { radialis }\end{array}$ & Normal & None & None & None & Normal & Normal & Normal & Normal & Normal & Full \\
\hline $\begin{array}{l}\text { L flexor carpi } \\
\text { ulnaris }\end{array}$ & Increased & $2+$ & None & None & Normal & Normal & $25 \%-50 \%$ & $\begin{array}{l}\text { Mildly } \\
\text { reduced }\end{array}$ & Normal & Full \\
\hline $\begin{array}{l}\text { L first dorsal } \\
\text { interosseous }\end{array}$ & Increased & $+/-$ & None & None & Normal & Normal & Normal & $\begin{array}{l}\text { Moderately } \\
\text { reduced }\end{array}$ & Increased & Full \\
\hline $\begin{array}{l}\text { L extensor } \\
\text { indicis } \\
\text { proprius }\end{array}$ & Normal & None & None & None & Normal & Normal & Normal & Normal & Normal & Full \\
\hline $\begin{array}{l}\text { L extensor } \\
\text { pollicis longus }\end{array}$ & Normal & None & None & None & Normal & Normal & $25 \%-50 \%$ & $\begin{array}{l}\text { Mildly } \\
\text { reduced }\end{array}$ & Increased & Full \\
\hline $\begin{array}{l}\text { L tibialis } \\
\text { anterior }\end{array}$ & Normal & None & None & None & Normal & Normal & Normal & $\begin{array}{l}\text { Mildly } \\
\text { reduced }\end{array}$ & Normal & Full \\
\hline $\begin{array}{l}\text { L } \\
\text { gastrocnemius }\end{array}$ & Normal & None & None & None & Normal & Normal & Normal & $\begin{array}{l}\text { Mildly } \\
\text { reduced }\end{array}$ & Normal & Full \\
\hline $\begin{array}{l}\text { L tibialis } \\
\text { posterior }\end{array}$ & Increased & $1+$ & None & None & Normal & Normal & $25 \%-50 \%$ & $\begin{array}{l}\text { Moderately } \\
\text { reduced }\end{array}$ & Increased & Full \\
\hline $\begin{array}{l}\text { L vastus } \\
\text { lateralis }\end{array}$ & Increased & $2+$ & None & None & Normal & Normal & $25 \%-50 \%$ & $\begin{array}{l}\text { Moderately } \\
\text { reduced }\end{array}$ & Normal & Full \\
\hline $\begin{array}{l}\mathrm{L} \text { adductor } \\
\text { longus }\end{array}$ & Increased & $1+$ & None & None & Normal & Normal & Normal & $\begin{array}{l}\text { Mildly } \\
\text { reduced }\end{array}$ & Normal & Full \\
\hline $\begin{array}{l}\text { L gluteus } \\
\text { medius }\end{array}$ & Normal & None & None & None & Normal & Normal & Normal & Normal & Normal & Full \\
\hline $\begin{array}{l}\text { L lumbar } \\
\text { paraspinalis }\end{array}$ & Increased & $1+$ & None & None & & & & & & \\
\hline $\begin{array}{l}\text { L cervical } \\
\text { paraspinalis }\end{array}$ & Increased & $1+$ & None & None & & & & & & \\
\hline
\end{tabular}

Abbreviation: $\mathrm{IA}=$ insertional activity.

GO TO SECTION 3 


\section{Section 3}

Nerve conduction studies showed conduction block in left ulnar and median nerves in the forearm, along with mildly slowed sensory velocities of bilateral ulnar and left sural and right median nerve. Sensory nerve action potential amplitudes were mildly reduced in multiple nerves (bilateral median and radial, right ulnar, and left sural). The F-wave latency of left ulnar nerve was also prolonged ( $\sim 130 \%$ of normal). Needle EMG showed neuropathic units in L4/5, L5/S1, and C7-T1innervated muscles. These findings are consistent with the presence of multiplex mononeuritis with demyelinating pattern and polyradiculopathy.

IV immunoglobulin (IVIg) treatment $(2 \mathrm{~g} / \mathrm{kg})$ over 5 days was administered, after which there was improvement in distal muscle strength.

The patient's recent weight loss and mildly elevated CSF cell count $>10 / \mu \mathrm{L}$ prompted further workup for systemic disease. Contrast-enhanced CT of the chest, abdomen, and pelvis showed lymphadenopathy in the mediastinum, upper abdomen, and hilar regions. Endobronchial ultrasound-guided bronchoscopy was performed, and the tissue biopsy demonstrated noncaseating granulomas without evidence of fungi or acid-fast bacilli, which was consistent with sarcoidosis. Based on the diagnostic criteria recently proposed by the Neurosarcoidosis Consortium Consensus Group-(1) definite when there is histologic confirmation of neurologic tissue, (2) probable when there is evidence of neurologic involvement and tissue confirmation of systemic sarcoidosis, and (3) possible when characteristic neurologic involvement is seen in the absence of any tissue diagnosis of sarcoidosis-the diagnosis of probable neurosarcoidosis was made. ${ }^{2,3}$ Nerve biopsy was deferred since the patient was clinically improving. The patient was subsequently discharged on oral prednisone at $60 \mathrm{mg}$ daily. At 1-month outpatient follow-up, he demonstrated substantial improvement as he was able to ambulate without assistance for a short distance.

\section{Discussion}

Peripheral neuropathy is an uncommon presentation of neurosarcoidosis, with an estimated frequency between $5 \%$ and $18 \%{ }^{4}$ Nerve damage is usually a result of local pressure from epineural and perineural granulomas and necrotizing vasculitis via proteolytic enzymes secreted by epithelioid cells. ${ }^{5}$ The types of neuropathy that have been reported include cranial polyneuropathy, painful axonal sensory neuropathy, Guillain-Barré syndrome, and small fiber neuropathy. The asymmetric subacute progression seen in our case is relatively uncommon although a case of multifocal neuropathy with conduction block as seen in our case has been reported in a case series. ${ }^{5}$

The abnormalities on CSF analysis and systemic symptoms guided our investigation. According to a systematic review of neurosarcoidosis, pleocytosis was seen in 58\% and elevated CSF protein in $63 \%$ of all patients with neurosarcoidosis, both of which were observed in the patient presented. ${ }^{6}$ CSF angiotensin-converting enzyme analysis was not performed due to its relatively low sensitivity (66.7\%) and specificity $(67.3 \%){ }^{6}$ Weight loss is also common in neurosarcoidosis. Burns et al. ${ }^{7}$ reported that constitutional symptoms, such as fatigue, malaise, fever, and unexplained weight loss, were seen in $49 \%(28 / 57)$ of patients with limb neuropathy with neurosarcoidosis. Concurrent CNS involvement is relatively uncommon and seen in fewer than $25 \%$ of peripheral neuropathy cases.

Based on the electrodiagnostic features with demyelinating changes and asymmetric sensory and motor involvement, the patient was initially treated with 5 days of IVIg therapy empirically as we considered atypical CIDP a possible diagnosis. Of note, the patient showed improvement shortly after IVIg was given. However, following tissue diagnosis, corticosteroids were started for probable neurosarcoidosis. The standard first-line therapy for acute symptomatic neurosarcoidosis is corticosteroids at a dose of $0.5-1 \mathrm{mg} / \mathrm{kg} / \mathrm{d}$, and it may be necessary to give high-dose methylprednisone IV for 3 to 5 days for severe acute disease. ${ }^{8}$ In a prospective study of peripheral neurosarcoidosis, $86 \%(12 / 14)$ of patients responded to corticosteroids. ${ }^{9}$ Even though IVIg has been shown to be effective in some case reports with sensory predominant axonal polyneuropathy and small fiber neuropathy, its efficacy for peripheral neurosarcoidosis has not yet been established. The fact that our patient improved with IVIg before corticosteroids may indicate its effectiveness in peripheral neurosarcoidosis.

A systematic review of 1,088 patients with neurosarcoidosis revealed that $24 \%$ of them needed a second- or third-line therapy following steroid therapy. Various steroid-sparing agents including azathioprine, methotrexate, tumor necrosis factor- $\alpha$, mycophenolate mofetil, cyclophosphamide, and cyclosporine have been used and $55 \%$ of patients with secondline therapy had favorable outcomes. There are no reports of randomized placebo-controlled trials establishing the efficacy of a long-term therapeutic regimen in systemic sarcoidosis. Methotrexate has been used most widely along with equivocal results from azathioprine and mycophenolate. ${ }^{10}$ Even though we expect similar efficacy of these agents for the treatment of neurosarcoidosis, our patient has shown substantial improvement with IVIg and corticosteroids without the need for a steroid-sparing agent to date.

\section{Author contributions}

Y. Harada: patient clinical care and follow-up, manuscript conception, writing of the first draft. H. Elkhider: patient clinical care, writing of the first draft. M. Lotia: patient clinical care and follow-up, manuscript conception, review, and critique. N. Masangkay: patient neurodiagnostics and follow-up, manuscript review and critique. 


\section{Study funding}

No targeted funding reported.

\section{Disclosure}

The authors report no disclosures relevant to the manuscript. Go to Neurology.org/N for full disclosures.

\section{References}

1. Barohn RJ, Amato AA. Pattern-recognition approach to neuropathy and neuronopathy. Neurol Clin 2013;31:343-361.

2. Zajicek JP, Scolding NJ, Foster O, et al. Central nervous system sarcoidosis: diagnosis and management. QJM 1999;92:103-117.

3. Stern BJ, Royal W III, Gelfand JM, et al. Definition and consensus diagnostic criteria for neurosarcoidosis: from the Neurosarcoidosis Consortium Consensus Group. JAMA Neurol 2018;75:1546-1553.
4. Ungprasert P, Carmona EM, Utz JP, Ryu JH, Crowson CS, Matteson EL. Epidemiology of sarcoidosis 1946-2013: a population-based study. Mayo Clin Proc 2016;91 183-188.

5. Said G, Lacroix C, Planté-Bordeneuve V, et al. Nerve granulomas and vasculitis in sarcoid peripheral neuropathy: a clinicopathological study of 11 patients. Brain 2002; 125:264-275.

6. Bridel C, Courvoisier DS, Vuilleumier N, Lalive PH. Cerebrospinal fluid angiotensin-converting enzyme for diagnosis of neurosarcoidosis. J Neuroimmunol 2015;285:1-3.

7. Burns TM, Dyck PJ, Aksamit AJ, Dyck PJ. The natural history and longterm outcome of 57 limb sarcoidosis neuropathy cases. J Neurol Sci 2006;244: 77-87.

8. Terushkin V, Stern BJ, Judson MA, et al. Neurosarcoidosis: presentations and management. Neurologist 2010;16:2-15.

9. Allen RK, Sellars RE, Sandstrom PA. A prospective study of 32 patients with neurosarcoidosis. Sarcoidosis Vasc Diffuse Lung Dis 2003;20:118-125.

10. Baughman RP, Lower EE. Treatment of sarcoidosis. Clin Rev Allergy Immunol 2015; 49:79-92.

\section{Disputes \& Debates: Rapid online correspondence}

The editors encourage comments on recent articles through Disputes \& Debates:

Access an article at Neurology.org/ $\mathrm{N}$ and click on "COMMENT" beneath the article header. Responses will be posted within 3 business days.

Before submitting a comment to Disputes \& Debates, remember the following:

- Disputes \& Debates is restricted to comments about studies published in Neurology within the last eight weeks

- Read previously posted comments; redundant comments will not be posted

- Your submission must be 200 words or less and have a maximum of five references; reference one must be the article on which you are commenting

- You can include a maximum of five authors (including yourself)

\section{Sign Up for the AAN's Axon Registry}

The AAN encourages its US members to show their interest in participating in the Axon Registry by signing up today.

Use the Axon Registry to:

- Simplify reporting requirements under MACRA’s Quality Payment Program and avoid penalties while reducing your administrative burden

- Meet your MOC Part IV requirements and waive up to eight credits of Part II Self-Assessment

- Choose from 22 AAN neurology-specific quality measures that fit your practice

- Use data to understand your practice and identify where improvements can be made to patient care

- Manage your patients at a population level; look at a specific group of patients based on conditions, risk factors, demographics or outcome

- Demonstrate your value to payers when negotiating reimbursement

- Enjoy multi-year, fee-free access when you sign the agreements and integrate your EHR with the registry

Learn more at AAN.com/view/Axon and send your questions to registry@aan.com. 


\section{Neurology}

Clinical Reasoning: A 65-year-old man with asymmetric weakness and paresthesias Yohei Harada, Hisham Elkhider, Neil Masangkay, et al.

Neurology 2019;93;856-861

DOI 10.1212/WNL.0000000000008444

This information is current as of November 4, 2019

\section{Updated Information \&} Services

References

Subspecialty Collections

Permissions \& Licensing

Reprints including high resolution figures, can be found at: http://n.neurology.org/content/93/19/856.full

This article cites 10 articles, 0 of which you can access for free at: http://n.neurology.org/content/93/19/856.full\#ref-list-1

This article, along with others on similar topics, appears in the following collection(s):

\section{All Neuromuscular Disease}

http://n.neurology.org/cgi/collection/all_neuromuscular_disease Peripheral neuropathy

http://n.neurology.org/cgi/collection/peripheral_neuropathy

Information about reproducing this article in parts (figures,tables) or in its entirety can be found online at:

http://www.neurology.org/about/about_the_journal\#permissions

Information about ordering reprints can be found online:

http://n.neurology.org/subscribers/advertise

Neurology ${ }^{\circledR}$ is the official journal of the American Academy of Neurology. Published continuously since 1951, it is now a weekly with 48 issues per year. Copyright @ 2019 American Academy of Neurology. All rights reserved. Print ISSN: 0028-3878. Online ISSN: 1526-632X.

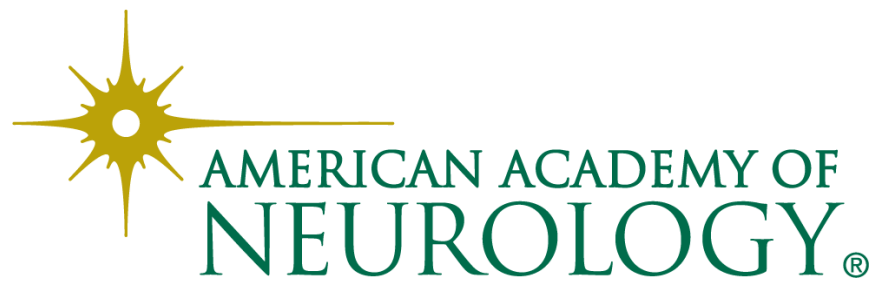

